\title{
The relationship between Salmonella infection and liver fluke infestation in slaughter sheep
}

\author{
N. K. Al-Nakeeb \\ F. G. Habasha \\ nawrasalnakeeb@yahoo.com \\ Coll. of Vet. Med. Al-Qadesyia \\ Coll. of Vet. Med. Baghdad
}

\begin{abstract}
The study aimed to detect the relationship between Salmonella infection and liver fluke infestation in slaughter sheep and the association of them with sex and age.Two hundred forty Awassi sheep were divided into two groups, first group(120)healthy animals free from liver fluke (control group), while the second group(120) animals infected with liver fluke(infected group ). Different samples were collected from all animals includes, liver, bile, fecal samples and liver fluke were conducted to bacteriological and serological examination for detection of Salmonella and parasitological examination for detection of Fasciola spp. Results revealed that the percentage of Salmonella isolated from control group were $(15 \%)$ while in the infected group were $(25.83 \%)$. According to samples, liver ,fecal samples and liver fluke showed a higher percent of Salmonella infection in the infected group in comparison with control group with a significant difference at $(\mathrm{p}<0.05)$.A high percent of isolation of Salmonella from male $(23.07 \%)$ than the percentage in female $(8.82 \%)$. Moreover results indicated high percentage isolate of Salmonella in animals aged 3-4 years.
\end{abstract}

\section{Introduction}

Salmonellosis is one of few diseases that are increasing in prevalence (1).Salmonella is zoonotic pathogen that is capable of infection for humans and domestic animals (2). Salmonella infections are usually confined the gastrointestinal tract characterized by acute diarrhea and fever and are generally self limited $(3,4)$. The prevalence of infection varies among species and countries and is much higher than the incidence of clinical disease ,which is commonly precipitated by stressful situations such as sudden deprivation of feed transportation, drought, crowding ,parturition and administration of some drug (5).Moreover there are often non-infectious predisposing disease such as parturient paresis ,ketosis, mastitis and parasitic infestation(6,7).In Baghdad city, Al-Talib

\section{Materials and methods}

Animals:- Two hundred forty slaughtered Awassi sheep were used in this study the sheep divided into two groups

- Group 1:-(Control group) composed of 120 slaughtered sheep from different age and sex and they had not infected with liver flukes.
(8) was record a percentage of $4.8 \%$ of Salmonella in sheep with (11) isolates 3 isolates from 140 fecal diarrheal samples and 8 isolates from 85 gall bladder samples)and these isolates belongs to $S$. enteritidis and S.newport serotypes. AlSanjary(9) was report different percentage of Salmonella infection in different organs and feces of goat and sheep in Mousl city in Iraq.There is also some evidence which indicate that liver fluke infected cattle is more susceptible to infection with S.dublin than cattle free of liver fluke. The same is likely to be true for sheep $(10,11)$. The objective of this study was to determine the percentage of Salmonella isolates in liver ,bile and fecal samples in normal sheep compared to infected sheep with liver flukes.

- Group 2:-(Infected group ) composed of 120 slaughtered sheep infected with liver fluke from different ages and sex.

This study has been started from march to December 2006 and samples were collected from different slaughter houses in Al- 
Diwanya ,Al-Shamiya, Afak and AlDaghara (in Al-Qadesyia governorate).

Samples collected according to Coles(12). 240 liver samples from both groups ;240 bile samples; 240 Fecal samples were collected directly from rectum of slaughtered sheep and examined for Salmonella and for liver fluke and 120 liver fluke (Fasciola) samples collected from bile duct of infected sheep only.

\section{Bacterial isolation}

All samples were conducted for bacterial isolation .liver, bile, Fasciola ( minised) and fecal samples by cultured them in tetrathionate broth and incubated at 37 for 24 hours .Then sub- cultured on Salmonella -Shigella agar and incubated under same condition, the isolates were identified according to their morphology ,size, color and shape of colonies .biochemical tests and serological diagnosis were conducted according to the method of (13) .

Parasite isolation:-Sedimentation procedure to detect the presence of fluke eggs in the feces (12).Statistical analysis :-Chi square $\mathrm{x}$ 2 was used to compare between two groups (14).

\section{Results}

Infected sheep with liver fluke give positive result for Salmonella in 31 animals out of 120 animals with a percentage of $25.83 \%$ while in the control group positive result was 18 animals out of 120 with a percentage of $15 \%$. There was a relation between isolation of Salmonella and liver fluke infestation and this relation was statistically significant at $(\mathrm{p}<0.05)$ as showed in table( 1$)$.

Table (1) Isolation of Salmonella in both groups according to animals

\begin{tabular}{|c|c|c|c|c|}
\hline Sheep & +ve for Salmonella & $\%$ & -ve for Salmonella & $\%$ \\
\hline Infected with liver fluke & 31 & 25.83 & 89 & 74.17 \\
\hline Control & 18 & 15 & 102 & 85 \\
\hline Total & 49 & 20.41 & 191 & 79.59 \\
\hline
\end{tabular}

(+ve): No. of positive Salmonella isolates ; (-ve): No. of negative Salmonella isolates

Salmonella species were isolated from different samples of 49 slaughtered sheep
.The total numbers of isolates were 67 with a percentage of $7.97 \%$,(table 2).

Table (2) Salmonella isolated from different samples

\begin{tabular}{|c|c|c|c|c|c|}
\hline Samples & $\begin{array}{c}\text { Total } \\
\text { no. }\end{array}$ & $\begin{array}{c}\text { No of samples +ve } \\
\text { Salmonella }\end{array}$ & $\%$ & $\begin{array}{c}\text { No of samples -ve } \\
\text { Salmonella }\end{array}$ & $\%$ \\
\hline Liver & 240 & 28 & 11.66 & 212 & 88.34 \\
\hline Bile & 240 & 4 & 1.66 & 236 & 98.34 \\
\hline Feces & 240 & 30 & 12.5 & 210 & 87.5 \\
\hline Liver fluke & 120 & 5 & 4.16 & 115 & 95.84 \\
\hline Total & 840 & 67 & 7.97 & 773 & 92.03 \\
\hline
\end{tabular}

Regarding the Salmonella isolates percentage from different samples of both control and infected sheep groups were observed in table (3), statically difference recorded in infected group in liver and fecal samples and liver fluke itself at $(\mathrm{p}<0.05)$. 
Table(3) Salmonella isolates percentage from both sheep groups according to different samples

\begin{tabular}{|l|l|l|l|l|l|l|l|l|}
\hline \multirow{2}{*}{ Samples } & \multicolumn{4}{|c|}{ Control } & \multicolumn{4}{c|}{ Infected } \\
\cline { 2 - 10 } & $+\mathrm{ve}$ & $\%$ & $-\mathrm{ve}$ & $\%$ & $+\mathrm{ve}$ & $\%$ & $-\mathrm{ve}$ & $\%$ \\
\hline Liver & 6 & 5 & 114 & 95 & 22 & 18.33 & 98 & 81.67 \\
\hline Bile & 3 & 2.5 & 117 & 97.5 & 1 & 0.83 & 119 & 99.17 \\
\hline Fecal samples & 10 & 8.33 & 110 & 91.67 & 20 & 16.66 & 100 & 83.34 \\
\hline Liver fluke & - & - & - & - & 5 & 4.16 & 115 & 95.84 \\
\hline
\end{tabular}

(+ve): No. of positive Salmonella isolates ; (-ve): No. of negative Salmonella isolates

The results of culture of liver fluke itself from sheep infected with liver fluke showed that salmonella have been isolated from 5 out of 120 samples with percentage $(4.16 \%)$ as showed in table (2). It has been indicated a significant $(\mathrm{p}<0.05)$ correlation between Salmonella and liver fluke infestation in females where as no significant correlation were detected in males. table(4)

Table (4)percentage of Salmonella in both groups of sheep according to their sex.

\begin{tabular}{|l|l|l|l|l|l|l|l|l|}
\hline \multirow{2}{*}{ Sex } & \multicolumn{5}{|c|}{ Control } & \multicolumn{4}{c|}{ Infected } \\
\cline { 2 - 10 } & + ve & $\%$ & - ve & $\%$ & +ve & $\%$ & - ve & $\%$ \\
\hline Female & 6 & 8.82 & 62 & 91.17 & 13 & 20.31 & 51 & 79.69 \\
\hline Male & 12 & 23.07 & 40 & 76.93 & 18 & 32.14 & 38 & 67.86 \\
\hline Total & 18 & 15 & 102 & 85 & 31 & 25.83 & 89 & 74.17 \\
\hline
\end{tabular}

(+ve): No. of positive Salmonella isolates ; (-ve): No. of negative Salmonella isolates

In all age groups there were differences in the percentage of Salmonella isolated in both groups ,but the difference between two groups in female group were statistically not significant $(\mathrm{P}<0.05)$ table 5 .

Table (5) percentage of Salmonella isolated from female in both groups according to their age.

\begin{tabular}{|l|l|l|l|l|l|l|l|l|l|}
\hline \multirow{2}{*}{ Age group } & \multicolumn{4}{|c|}{ Control } & \multicolumn{4}{c|}{ Infected $x^{2}$} \\
\cline { 2 - 10 } & $+\mathrm{ve}$ & $\%$ & $-\mathrm{ve}$ & $\%$ & $+\mathrm{ve}$ & $\%$ & $-\mathrm{ve}$ & $\%$ & \\
\hline 6month-1 year & 1 & 14.28 & 6 & 85.72 & 1 & 25 & 3 & 75 & 0 \\
\hline 1-2 years & 1 & 5 & 19 & 95 & 3 & 27.27 & 8 & 72.73 & 3.42 \\
\hline 2-3 years & 0 & 0 & 14 & 100 & 3 & 16.66 & 15 & 83.34 & 1.7 \\
\hline 3-4 years & 1 & 10 & 9 & 90 & 2 & 40 & 3 & 60 & 1.88 \\
\hline 4-5 years & 2 & 20 & 8 & 80 & 1 & 8.33 & 11 & 91.67 & 1.71 \\
\hline 5-6years & 1 & 14.28 & 6 & 85.72 & 3 & 21.45 & 11 & 78.55 & 0 \\
\hline Total & 6 & 8.82 & 62 & 91.18 & 13 & 20.31 & 51 & 79.69 & - \\
\hline
\end{tabular}

The results indicated that there were difference in the percentage of Salmonella isolates from male in both groups according to their age, the differences were statistically significant as showed in table (6). 
Table (6) percentage of Salmonella isolated from male in both groups according to their age.

\begin{tabular}{|c|c|c|c|c|c|c|c|c|c|}
\hline \multirow[t]{2}{*}{ Age group } & \multicolumn{4}{|c|}{ Controle } & \multicolumn{4}{|c|}{ Infected } & \multirow[t]{2}{*}{$x^{2}$} \\
\hline & $+\mathrm{ve}$ & $\%$ & -ve & $\%$ & $+\mathrm{ve}$ & $\%$ & - ve & $\%$ & \\
\hline 6month-1 year & 1 & 6.66 & 14 & 93.34 & 3 & 14.28 & 18 & 85.72 & 1.2 \\
\hline $1-2$ years & 3 & 60 & 2 & 40 & 1 & 7.14 & 13 & 92.86 & 6.7 \\
\hline $\begin{array}{l}\text { More than 2-3 } \\
\text { years }\end{array}$ & 1 & 11.11 & 8 & 88.89 & 3 & 75 & 1 & 25 & 7.3 \\
\hline $\begin{array}{l}\text { More than } 3-4 \\
\text { years }\end{array}$ & 2 & 22.22 & 7 & 77.78 & 8 & 57.14 & 6 & 42.86 & 3 \\
\hline $\begin{array}{l}\text { More than } 4-5 \\
\text { years }\end{array}$ & 3 & 33.33 & 6 & 66.67 & 3 & 100 & 0 & 0 & 7.8 \\
\hline $\begin{array}{l}\text { More than 5- } \\
\text { 6years }\end{array}$ & 2 & 40 & 3 & 60 & 0 & 0 & 0 & 0 & 0 \\
\hline Total & 12 & 23.07 & 40 & 76.93 & 18 & 32.14 & 38 & 67.86 & - \\
\hline
\end{tabular}

(+ve): No. of positive Salmonella isolates ; (-ve): No. of negative Salmonella isolates

\section{Discussion}

Salmonellosis remains an important clinical problem in veterinary medicine not only because of animal infection caused by organism ,but also because of risks posed to humans from animal infections and animal products $(2,3,5)$. Clinical disease may develop from subclinical and latent infections if affected animals are stressed (15) fecal contamination of feed and water supplies with salmonella organism can cause outbreak in stressed sheep (16).Liver fluke infections in cattle can predispose cows to infectious disease such as Salmonellosis and the same in likely to be true for sheep (11).The results of this study revealed that the infection rate in control group was (15\%) which Salmonella has been isolated from different types of samples which represented carrier state as reported by $(5,17,18)$. The results agreed with previous studies in sheep, Al-Azawi (19); Nabbut and Al-Nakhli(20) which reported that the percentage of Salmonella was $14.7 \%$ in sheep, while this percentage was higher than the result of previous study by Mohammed (21) which was carried on fecal samples of sheep.The present study revealed low percentage of Salmonella isolates in liver, fecal samples and liver flukes in the control group While in the infected group a higher percentage of Salmonella isolates appeared in the liver; fecal samples and liver flukes with a statistically difference at $(\mathrm{P}<0.05)$ and $(\mathrm{P}<0.01)$. this percentage was more than the study of Al -Dulaimi (22) who reported that Salmonella isolated from liver and spleen at a percent of 2-3\%. .Breitischwerdt (23) was report that the Salmonella invade the payers patches and then disseminate to the lymph node, liver and spleen. Also our results was agree with previous study by Allen (5) who report that stressed sheep carry salmonella in their intestine and shed the infection in their dung when under stress .there is association between two groups and this association was statistically significant at $(\mathrm{P}<0.05)$.In the control group Salmonella isolated from male with percentage of $23.07 \%$ and from female $8.82 \%$ the difference was significant $=4.3$ ( $\mathrm{P}<0.05)$, the result agreed with (24) and the difference may be attributed to the hormonal differences which lead to the hormonal differences which lead to variation in the natural immunity between male and female (25).Regarding the results of Salmonella isolation according to their sex there was higher percentage in male $(32.14 \%)$ compared to female $(20.31 \%)$ the differences were statistically not significant at $\mathrm{P}>0.05$ that male and female were infected with liver flukes equally due to increase of their 
susceptibility to salmonella infection ,the stressed animals will increase steroid production and may become immunosuppressive and this will help precipitate the disease (26). The results of Salmonella isolation rate according to the age groups ,the higher rate was appeared in age 4-5 years in control group and the explanation for this that subclinical infections are observed in older animals and young animals rarely become carriers $(5,27)$ - The results in infected group showed a higher percentage in 3-4 years of age this result referred that the outcome of host pathogen interaction include immunity ,host dose and virulence of pathogen and environmental and management factors (23).

\section{References}

1.Smith BP.(1990).Large Animal Internal Medicine. T c.v. Mosby company. Baltimore, Philadelphia.

2.Gyles CL, Prescott JF, Songer JG, Theon CO.(2004). Pathogenesis of bacterial infections in animals. Third edition. U.S.A. Blackwell publishing company.

3. Thornley C, Baker M, Nicol C. ( 2002).The rising incidence of Salmonella infection in New Zealand, 1995-2001. New Zealand Public health report.;9:25-28.

4.Clarke R , Tomlin P.(2004) Salmonella Brandenburg; changing patterns of disease in southland province, New Zealand. J. New Zealand Med. Associ. Vol.117.No.205

5. Allen DG, Anderson DP,Jeffcott LB,Quesenberry EK , Radostitis OM , Reves PT, Wolf AM.(2005).The Merck Veterinary Manual :Salmonellosis. Ninth edition .Merck and co. Inc .USA.

6.Jubb KVF, Kennedy PC, Palmer N.( 1985) Pathology of domestic animals. Third edition. Vol.2. academic press. Sandiego. New York . London . U.S.A.

7.Hindson JC, Winter AC.(2002) Manual of sheep diseases. Blackwell publishing company .Oxford.

8.Al-Talib.(2010).Isolation and identification of Non -Typhoidal Salmonella from children and sheep in Baghdad city and compare the virulent of the zoonotic isolate in rabbits. [Master Thesis] college of Veterinary medicine .Baghdad University.
9. Al-Sanjary, R. A.(1999). Incidence of salmonella in lymph nodes, spleen $\&$ Feces of sheep \& goat slaughtered in Mosul abattoir. Iraqi. J.Vet.Sci.; 12(2) :p.359-364.

10.Malmo J.(2002). Liver fluke and milking cows. The Australian Veterinary Association .Petist.Com. Ltd.

11.Mccoy M, Kenny J.(2002). Liver fluke infection in sheep and cattle warning DARD. Media service Dundonald House ,Belfast BT 435B,Northern Ireland.

12. Coles EH. Veterinary clinical pathology. Second edition .W.B. Saunders company .Philadelphia ,London .Tornnto.1974.

13.Quinn PJ, Carter ME, Markey B, Carter GR.(2004). Clinical Veterinary microbiology. $6^{\text {th }}$ ed. Mosby an imp. Wolf , London.

14.Lama H.(1989).Statistical Method. The University institution for studies and publishing and distribution first edition .

15. Quinn PJ, Markey BK.(2009). Concise review of vet. Microbiology .Blacwell publishing company .Ltd.Oxford, Australia.

16.Court J, Seymour.(2003). Salmonellosis .Sheep drought: $6^{\text {th }}$ sheep health .Department of primary industries .state of Victoria1996-2006.

17.Cuneo SP.(2002). Farm animal zoonotic and reportable disease ; Salmonellosis .University Animal care .Tucson ,AZ.VSC./443/543.

18. Hirsh DC, Maclandchlan NJ, Walker RL.(2004). .Enterobacteriaceae: 
Salmonella. Veterinary microbiology .Second edition . Blackwell publishing . U.S.A . PP69-74 .

19.Al-Azawi AM.(1989). Incidence of Salmonella in lymph nodes,spleen and feces of sheep and goats slaughtered in Baghdad a battoir. Proc. $5^{\text {th }}$ conf.Scr. 7:152-157.

20.Nabbut NH, Al-Nakhli HM .( 1982).Incidence of Salmonella in lymph nodes ,spleen and feces of sheep and goats slaughtered in Riyadh public a abattoir. J.Food. Prot. 45:1314-1317.

21.Mohammed MMZ. Epidemiology of Salmonellosis in sheep in naenawa governorate with some immunization mehods in rabbits. Ph.D. Thesis .Dept. of medicine, College of Vet. Med. Baghdad University.

22.A1-Dulaimi HAM. (1994). Contamination of sheep meat with Salmonella bacterium in Al-Anbar governorate. Master thesis. Department of Vet.
Public health, College of Veterinary Medicine ,Baghdad University .Iraq .

23. .Breitschwedt EB, Davenport DJ, Paradis MR, Green R.(2000) Proceeding of the $18^{\text {th }}$ annual Veterinary Medical forum.

24. Molla W, Molla B, Alemayehu D, Muckle A, Cole L, Wilkie E.( 2006).Occurrence \& antimicrobial resistance of Salmonella serovars in Apparently healthy slaughtered sheep \& goat central ,Ethiopia. Trop. Anim. Health.Prod. 38 (6) : p455 - 62.

25.Miller JAP.( 1993).Elements of innate and acquired immunity .cited by Richard ,C And Geoffer S. Immunology a short Course $4^{\text {th }}$ ed. Library of Congress .USA.PP 17-36.

26.Tizard I.(2009).An introduction to Veterinary immunology ,Second edition .W.B. Saunders company ,Philadelphia, London . Toronto.

27.Tauxe RV.(1997).Evolving public health challenge . Emerging infectious diseases;3.425-434.

\section{العلاقة بين الإصابة بالسالمونيلا والخمج بديدان الكبد في الأغنام المذبوحة}

$$
\begin{aligned}
& \text { فيصل غازي حباشة } \\
& \text { نورس كاظم النقيب } \\
& \text { كلية الطب البيطري/ جامعة بغداد }
\end{aligned}
$$

استهدفت الدراسة التحري عن العلاقة بين الإصابة بالسالمونيلا والخمج بديدان الكبد في الأغنام وعلاقة ذلك بالجنس التساه

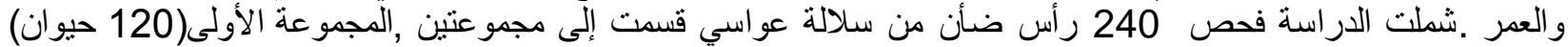

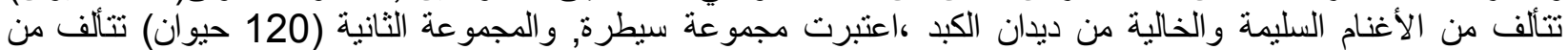

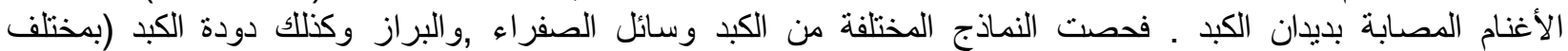

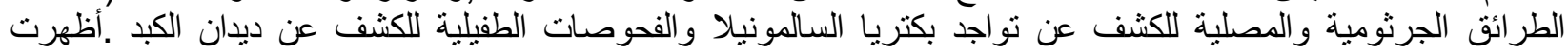

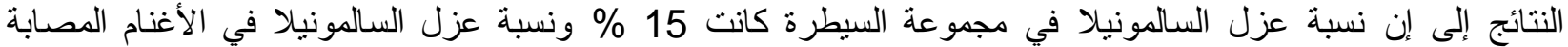
كانت 25.8\%. وتبعا للنماذج لوحظ إن الكبد والبراز وديدان الكبد أعلى نسبة إصـابة في المجموعة الثانية المصابة بديدان

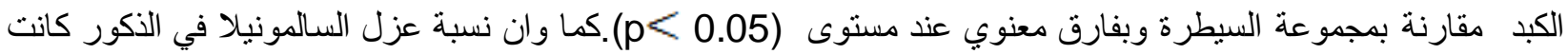

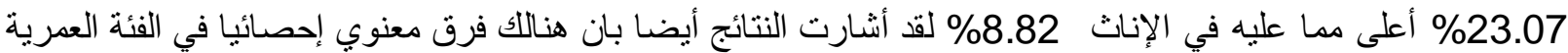

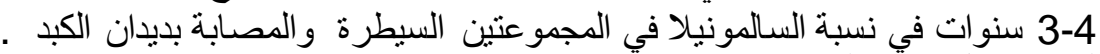

